\title{
Application Sorogan-Bandongan Model in Lectures Reaction Mechanism
}

\author{
Rinaningsih*, Suyatno Sutoyo \\ Department of Chemistry \\ Universitas Negeri Surabaya \\ Surabaya, Indonesia \\ rinaningsih@unesa.ac.id
}

\author{
Asep Kadarohman, Harry Firman \\ Department of Chemistry \\ Indonesia University of Education \\ Bandung, Indonesia
}

\begin{abstract}
Sorogan-Bandongan is an integrated lecture model coming from the traditional learning that are implemented at Islamic boarding school in Indonesia. It starts with Sorogan and ends with Bandogan. The implementation of integrated lecture model of Sorogan-Bandongan with stages of students reading and doing handout assignment; diagnostic test, material explanation by lecturer; students work on worksheets (Sorrogan); class discussion on reinforcing the material (Bandongan); final test. Sorogan-Bandongan becomes a lecture model in learning reaction mechanism with the average of handout assignments 51.8; diagnostic test 47.9; final test 60.4. The correlation between those three results is 0,511 . It is found that to learn reaction mechanism needed precondition configuration concept of electron, hybridization, molecular form, Lewis acid and base, and steric hindrance.
\end{abstract}

Keywords- model Sorogan-Bandongan, test diagnostic, learning reaction mechanism

\section{INTRODUCTION}

Reaction mechanism is a step-by-step description of chemical reaction event. This event of chemical reaction is an event on the molecular level that involves the outer shell of electron [1]. Tastan reveals that the difficulties in learning reaction mechanism include determinant of reaction speed and transition state [2]. These difficulties cause the lack of professionalism of the teacher in teaching reaction mechanism. Dicks has done a research by implementing several methods in lectures, so it can increase the attention [3]. Giving online assignment to the students has been done by Franz as it produced more effective lecturing method [4]. The same method is also done by Parker, working on online assignment with credit points which can improve the eagerness in learning [5]. Besides the method implementation in reaction mechanism lecture, spatial planning of classrooms can also improve performance capabilities [6]. The use of laboratories studio in $\mathrm{S}_{\mathrm{N}} 1$ and $\mathrm{S}_{\mathrm{N}} 2$ reaction mechanism lectures can also improve the confidence of the students [7]. The implementation of methods in reaction mechanism lectures can be done by giving assignment, classroom spatial planning, syllabus improvement and quizzes [8]. Giinersel did an integrated research to improve the involvements of the students, in this case positively correlated with their learning achievements $[9,10]$.

The difficulties in understanding reaction mechanism, besides caused by the lack of professionalism of the teacher in teaching reaction mechanism, it is also caused by the lack of implementation of several methods in reaction mechanism lecture. In understanding reaction mechanism concept, it needs to be understood by the way of sharing between the students in a discussion activity so they can improve their skill in thinking logically. Reaction mechanism lecture should be designed to facilitate the students with opportunity to discuss and thinking logically [11]. This discovery is fulfilled in the integrated lectures models of Sorogan - Bandongan. The development of integrated lecture of Sorogan - Bandongan is a fusion of Sorogan method and Bandongan method. Sorogan is an individual learning method while Bandongan is a discussion method for material sifting by student who understands the material better to the students that have not understood. This paper will discuss the result of research about the implementation of integrated lecture of SoroganBandongan model to determine the understanding of the students in learning reaction mechanism.

\section{Methodology}

Research method used is Mixed Method with Embedded Experimental Design model [12]. Data were described qualitatively and then the correlation between handout performance value, diagnostic test result and final test result quantitatively were analysed. Sample used in this research are 31 students from Chemistry Department of UNESA that takes Organic Chemistry I course on even semester, academic year of 2013/2014. Data of this research are diagnostic test, handout, learning result test and questionnaire. The outline of the Sorogan-Bandongan model is as follows: students read and do assignment on the handout; diagnostic test; material explanation by the lecturer; students work on worksheets; class discussion on reinforcing the material; final test. Data analysis was done using mixed method approach [12], which was firstly done qualitatively to describe the result of diagnostic test, handout assignment, final test result and students questionnaire. Secondly, to ensure there is a correlation between diagnostic test, handout assignment and final test result, quantitative approach is applied by using Statistics [13].

\section{RESULTS AND DISCUSSION}

Based on the questionnaire filled by the respondents, obtained 25 among 31 students reading the handout before attending the lecture. Out of 25 students that read the handout, 21 students stated that they understand the lecture 
easier after reading the handout. The percentage of students in understanding the material on the handout before the explanation by the lecturer is $64.0 \%$ (16 students) experienced difficulties in learning $\mathrm{S}_{\mathrm{N}} 1,40.0 \%$ (10 students) $\mathrm{S}_{\mathrm{N}} 2,40.0 \%$ (10 students) reaction mechanism, $12.0 \%$ (3 students) experienced difficulties in understanding how to fill the orbital, $20.0 \%$ ( 5 students) is unable to determine nucleophicility, and $16.0 \% \quad$ (4 students) experienced difficulties in determining hybridization. From the result of the questionnaire it is also obtained the student's appraisal of the lecturer's way of teaching, stated that the explanation of the lecturer was difficult to understand, because of the less precise use of language, also the material taught was too short. This is in accordance with the research done by Tastan [2]. From the result, it is emphasized that in the implementation of integrated lecture using SoroganBandongan model, there must be a work of the lecturer in the form of handout and students worksheets, so only professional educators can implement this model.

Chart below shows the result of diagnostic test on the difficulties in learning reaction mechanism substitution nucleophilic.

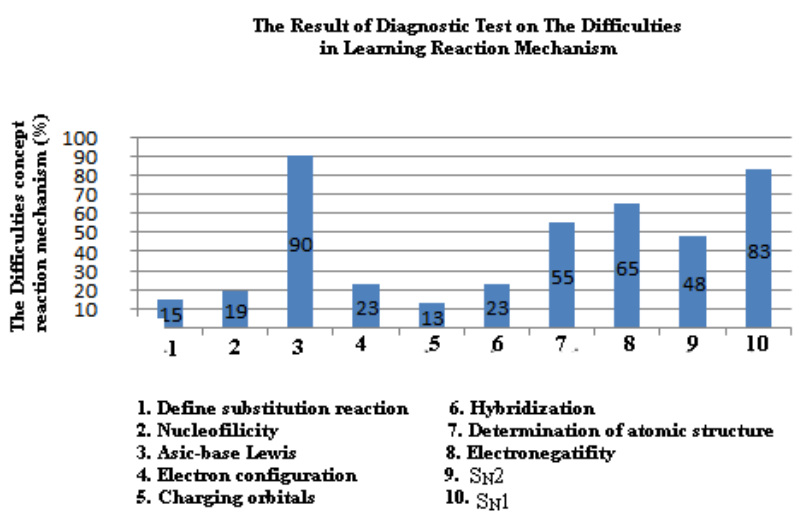

The result of diagnostic test used as consideration to step on the third syntax which is material explanation. The high percentage shows that material are increasingly difficult for the students, so that the emphasize on the material explanation is sorted according to the percentage of diagnostic test. The order of the material from the most difficult are Lewis acid and base, $\mathrm{S}_{\mathrm{N}} 1$, electronegativity, Lewis structure, $\mathrm{S}_{\mathrm{N}} 2$, electron configuration, hybridization and orbital filling. After the material explanation, students were asked to work on questions on the students worksheets. The lecturer tour around and give guide to the students that are having difficulties in learning individually. After finishing the worksheets individually (1) as material reinforcement, a class discussion was conducted (2). As for the final stage of the lecture, a learning result test was carried out (final test). The material difficulties on the final test can be exposed as follows: $3.0 \%$ students having difficulties in defining reaction substitution; $46.0 \%$ of the students having difficulties in understanding the concept of prerequisites; $4.5 \%$ students having difficulties on $\mathrm{S}_{\mathrm{N}} 1$; and $56.0 \%$ of the students having difficulties to differentiate between $\mathrm{S}_{\mathrm{N}} 1$ and $\mathrm{S}_{\mathrm{N}} 2$.

Determining the effectivity of the Sorogan - Bandongan model on the research can be done by comparing the diagnostic result of learning difficulties with material difficulties on the final test. It shows that there was drastic difficulties decline from $32.0 \%$ during the diagnostic test to $3.0 \%$ on the final test on definition of reaction substitution. Likewise, on the difficulties in learning $\mathrm{S}_{\mathrm{N}} 1$, the diagnostic test changes from $83.0 \%$ to only $4.5 \%$ and $\mathrm{S}_{\mathrm{N}} 2$ during diagnostic test from $48.0 \%$ to $20.0 \%$ on the final test. Prerequisite concept during the diagnostic test for Lewis acid and base is $90.0 \%$, electron configuration $23.0 \%$, orbital filling $13.0 \%$, hybridization $23.0 \%$, Lewis structure $55.0 \%$ and electronegativity $65 \%$. If averaged, concept of prerequisite on the diagnostic test is $44.0 \%$. That result is almost equivalent to the final test of $46.0 \%$. The equivalent shows that the concept of prerequisite needs its own time in lecture because of the limitation of time during the lecture's face to face interaction.

Difficulties in learning $\mathrm{S}_{\mathrm{N}} 1$ during diagnostic test and final test showed on the diagnostic test which amounted to $83.0 \%$ and final test $4.5 \%$. The difference of $78.5 \%$ between diagnostic test and final test illustrates that this model is effective if used in learning $\mathrm{S}_{\mathrm{N}} 1$. This illustration shows that the implementation of Sorogan - Bandongan integrated model can solve the difficulties in learning for the students. Students' difficulties in determining the structure formula become the obstacle for the students in determining the chemical equation; when they are unable to differentiate between primary, secondary and tertiary alkyl halide, students cannot determine whether the compound undergo $\mathrm{S}_{\mathrm{N}} 1$ or $\mathrm{S}_{\mathrm{N}} 2$ reaction, Structure formula greatly influences the existence of steric hindrance of a compound in determining whether the compound has $\mathrm{S}_{\mathrm{N}} 1$ or $\mathrm{S}_{\mathrm{N}} 2$ reaction. In this research the improvised final test is very appropriate to measure the ability of the students in understanding the material of nucleophilic substitution with the integrated model of Sorogan - Bandongan. This is in accordance with the studies done by the previous researcher which methods are implemented in integrated lecture $[9,10]$ with the syllabus development and quizzes/test [8] could improve the learning interest [5].

The decline of the average percentage from the result of diagnostic test compared with the result of the final test shows that integrated model of Sorogan - Bandongan can increase the effectivity of lectures. This discovery is in line with the previous studies, showing that the implementation of several methods in reaction mechanism lectures can improve the attention [3], involving students, centered on students [4], increasing learning interest [5], improving performance capabilities [6], and confidence [7].

The discovery resulted in this research is that students find difficulties in differentiating the $\mathrm{S}_{\mathrm{N}} 1$ and $\mathrm{S}_{\mathrm{N}} 2$ reaction mechanism, which is caused by that students not mastering the concept of prerequisite electron configuration, hybridization, molecular form, Lewis acid and base, and steric hindrance. The percentage of difficulties in prerequisite concept, and $\mathrm{S}_{\mathrm{N}} 1$ and $\mathrm{S}_{\mathrm{N}} 2$ reaction mechanism are equal, amounted to $46.0 \%$ and $56.0 \%$. The prerequisite concept still has high percentage $(46.0 \%)$, even almost equals to the diagnostic test $(44.0 \%)$. This is caused by the lack of time in the third step which is material explanation. Lecture duration in structured manner is only 2 credit hours (100 minutes) meanwhile to finish the prerequisite concept it can take up to 2 meetings. 
Prerequisite concept that has the highest percentage is Lewis acid and base with $90.0 \%$. Lewis acid and base actually have been studied on the basic chemistry course and studied again in details in chapter I of Organic Chemistry I, which is about the Structure of Atom and Molecules. This concept is closely related with the electronegativity and chemical bond as the determiner in understanding the reaction mechanism; because the reaction mechanism is a movement of electron on the outermost shell for the occurrence of reaction with other compound. So if students do not understand the Lewis acid and base, then they will not be able to determine the reaction mechanism. Therefore the difficulties percentage of Lewis acid and base, and reaction mechanism is equal. In this research, it is found that out of 31 students as sample, only 4 students were able to work perfectly on the reaction mechanism during the final test.

Based on statistical correlation between three variables (diagnostic test, handout and final test), it is obtained the correlation coefficient $\mathrm{R}$ of 0,511 which means there is moderate or enough relationship between diagnostic test result, reading and working on the handout, and final test result [13].

\section{CONCLUSIONS}

1. The learning of reaction mechanism of nucleophilic substitution requires the understanding of prerequisite concept of electron configuration, hybridization, molecular form, Lewis acid and base, and steric hindrance.

2. The implementation of integrated model of Sorogan Bandongan can improve lecture effectivity of nucleophilic substitution material and it is discovered that students experience difficulties in differentiating $\mathrm{S}_{\mathrm{N}} 1$ and $\mathrm{S}_{\mathrm{N}} 2$ reaction mechanism.

\section{REFERENCES}

[1] Ahiakwo, Macson, J. Organic Reaction Mechanism Controversy: Pedagogical Implication for Chemical Education. AJCE , 2(2), February 2012, Pp.51-65

[2] Tastan,O., Yalcinkaya, E., Boz, Y. Pre-Service Chemistry Teachers' Ideas about Reaction Mechanisme. Journal of Turkish Science Education, March 2010, Volume 7, Issue 1.

[3] Dicks, P.A., Lauten, M., Koroluk, J.K., Skonieczny, T., (2012) Undergraduate Oral Examinations in a University Organic Chemistry Curriculum. Journal of Chemical Education. Published: October 18, Pp. 1506-1510

[4] Franz, K., A. Organic Chemistry You Tube Writing Assignment for Large Lecture Classes. Journal of Chemical Education. Published: 2011, November 29. Pp. 497-501

[5] Parker, L.L., Loudon, M.,G. Case Study Using Online Homework in Undergraduate Organic Chemistry: Result and Student Attitudes. Journal of Chemical Education. Published: 2012, November 12, Pp. 37-44

[6] Muthyala, S.R., Wei, W. Does Space Matter? Impact of Classroom Space on Student Learning in an Organic-First Curriculum. Journal of Chemical Education. Published: 2016, November 26, Pp. 45-50

[7] Collison, G..C., Cody, J., Stanford, C. An $\mathrm{S}_{\mathrm{N}} 1-\mathrm{S}_{\mathrm{N}} 2$ Lesson in an Organic Chemistry Lab Using a Studio-Based Approach. Journal of Chemical Education. Published: March 21, 2012 Vol.89, Pp. 750754

[8] Aldahmash, H.A., Abraham, R.M. Kinetic Versus Static Visual for Facilitating College Students Understanding of Organic Reaction Mechanisme in Chemistry. Journal of Chemical Education. Published: 2009, December, Vol.86 No. 12: Pp. 1442-1446

[9] Giinersel, B.A., Fleming, A.,S. Qualitative Assessment of a 3D Simulation Program: Faculty, Students, and Bio-Organic Reaction. Journal of Chemical Education. Published: 2013, June 25, Pp. 988994

[10] Kenzie, Mc.N., Nulty, Mc.J., Leod, Mc.D., Fadden, Mc.M., Balachandran, N. Synthesizing Novel Anthraquinone Natural Product-Like Compounds to Investigate Protein-Ligand Interaction in Both an in Vitro and in Vivo Assay: an Integrated ResearchBased Third- Year Chemical Biology Laboratory Course. Journal of Chemical Education. Published: 2012, April 6, Pp. 743-749

[11] Mercer, M.,S., Andraos, J., Jessop, G..P. Choosing the Greenest Synthesis: A Multivariate Metric Green Chemistry Exercise. Journal of Chemical Education. Published: 2011, December 5, Pp. 215-220

[12] Creswell, W. J. Educational Research (planning, Conducting, and Evaluating Quantitative and Qualitative Research) (Third edition). Canada: Pearson Education, Inc, 2008.

[13] Sharma, S. Applied Multivariate Techniques. Canada: John Wiley \& Sons, Inc, 1996. 